\title{
Total Synthetic Development and Pharmacological Screening of Bioactive Isolated from Syzygium cuminii $(l)$ Skeel
}

\author{
Nikhat Farhana $1, *$ (D) \\ 1 Anjuman-I-Islam's Kalsekar Technical Campus, Plot No. 2 \& 3, Sector - 16, Near Thana Naka, Khandagao, New Panvel, \\ Navi Mumbai, Maharashtra 410206, India \\ 2 University of Mumbai,CST Road, Kolivery Village, Vidya Nagari, Kalina, Santacruz East, Mumbai, Maharashtra 400098, \\ India \\ * Correspondence: nik.nida13ada25@gmail.com;
}

Scopus Author ID 56236844500

Received: 15.04.2020; Revised: 9.05.2020; Accepted: 11.05.2020; Published: 13.05.2020

\begin{abstract}
Syzygium cumini (L.) Skeels (or Eugenia jambolana) is a species that belongs to the Myrtaceae family been used empirically to treat various diseases, one of them is antidiabetic. The study reported the phytochemical analysis and pharmacological screening of In-vivo, antidiabetic test conducted on bioactive (separated by column isolation method from aqueous extract) in streptozotocine induced diabetes rat modelling at dose level of $50 \mathrm{~g} / \mathrm{kg} \mathrm{BW}$, on the basis of TLC and spectral analysis of activity guided bioactive will be chemically designate as 4-(2-amino-2 -(2-(2-hydroxy-3-methyl butyl) octahydropyrrolo-[1,2-a] pyrazin-7-yl)-ethyl)-2- ethylpheno (ScReX-2), Total synthetic methodology accomplished using key BoC protected, pyrazine and methyl amine followed by condensation with application of simple Diels-alder reaction of fragment by cyclization. The Structure elucidation of the newly synthesized ScReX-2 was performed by means of FT-IR, ${ }^{1} \mathrm{H}-\mathrm{NMR},{ }^{13} \mathrm{C}-\mathrm{NMR}$, the antidiabetic activity showed that the effect of synthesized molecule at dose level of $50 \mathrm{mg} / \mathrm{kg} \mathrm{BW}$ was exhibits more potent significantly then glibenclamide to reduce the blood glucose levels subset of the statistics ANOVA ( $p>0.05$ ). The study concludes that the synthesized bioactive is having potent antidiabetic activity then compared with isolated molecule as well as glibenclamide.
\end{abstract}

Keywords: Syzygium cumiini L skeel; myretaceae; bioactive; total synthesis; antidiabetic; glibenclamide.

(C) 2020 by the authors. This article is an open access article distributed under the terms and conditions of the Creative Commons Attribution (CC BY) license (https://creativecommons.org/licenses/by/4.0/).

\section{Introduction}

Medicinal plants are the "backbone" to traditional medicine utilized by ancient civilization since prehistoric time, for prevention, mitigation, treatment and cure of several diseases, disorders and their elements [1]. Most of the medicinal plants around the world are rich resources of ingredients that could be used for drug development and synthesis [2]. Apart from the traditional use of medicinal plants for the herbal remedies, there has been an increasing reliance on their use in the industrialized societies, for the extraction and development of several drugs and chemotherapeutics [3]. Among the treasure of medicinal plants, Syzygium cumini (L.) Skeels (or Eugenia jambolana) is a species that belongs to the Myrtaceae family, and has potent antidiabetic, antioxidant, and anti-inflamatory activities [4]. Moreover, the plant has food value with potent chemopreventive, radioprotective, and antineoplastic activities [5]. 
The medicinal uses of Syzygium cumini (L.) Skeels found to be actively reported and recognized[6] in various systems of traditional and folk medicine, Syzygium cumini (L.) Skeels as one of the world's most commonly used plants for the treatment of diabetes, reported that phyto-chemistry of Syzygium cumini (L.) Skeels, leaves have potent medicinally active constituents like terpenoids[7], alkaloids[8], lignans, and phenolics, including quercetin, myricetin, sito-sterolmyricetin, and betulinic acid. In addition, many studies reported, different parts of the plants from this species (like seeds, bark, and flowers) have similar kinds of bioactives (such as flavonoids, phenolic acids[9], tannins, terpenes[10], quercetin, myricetin[11], myricitrin, kaempferol, and their glucoside derivatives), simple phenols (like ellagic acid, ferulic acid, chlorogenic acid, and gallicacid), and essential oils[12] (like $\alpha$-pinene, $\beta$-pinene, $\alpha$-limonene, $\alpha$-cadinol, pinocarvone, and pinocarveol) [13], Identified that the bright violet colour of the fruit is due to the presence of anthocynins, cyanidin, delphinidin, and petudinine. Many researchers [14] observed the application and utilization of the crude extracts of leaves, seeds, and stembark of Syzygium cumini (L.) Skeels possess excellent anti-allergic, antihyperglycaemic, anti-hyperlipidemic, antioxidant, antiviral, antibacterial, antifungal, and trypanocidal properties. The powdered jamun seeds and leaves in the form of decoctions are widely used in the treatment and management of diabetes, and were shown to have potent symptomatic relief along with regulation of blood glucose in type-2 diabetics[15].

The author's previous study [16]the root of Syzygium cumini (L.) Skeels for the presence of derivatives of flavonoids, glycosides, quarecityn, myrestine glycoside, and alleginic acid, which were isolated from the aqueous extract in good yield. The study also showed the reduction of blood glucose level in streptozotocine-induced diabetic rat with administration of $250 \mathrm{mg} / \mathrm{kg}$ bioactive (derivatives of flavonol).

The literature suggests that the antihyperglycemic activity of Syzygium cumini (L.) Skeels can be attributed to the antioxidant properties of flavonoids such as quercetin and rutin, which have been identified in Syzygium cumini (L.) Skeels leaf [17]. Thus, in the present study, we took advantage to select the root part to explore the bioactive and screen it for antidiabetic activity, in streptozotocine-induced diabetic rats model (well-known animal model to for screening antidiabetic activity) [18]. The main bioactive was isolated within the activity-guided extract responsible for the activity[19], and the total synthetic model was developed by following retrosynthetic analysis, in order to develop the synthetic strategy by controlling both stereochemistry and regiochemistry of the Diels \pm Alder reaction. This was the first time approach in the field of synthetic bioactive isolation from Syzygium cumini (L.) Skeels.

\section{Materials and Methods}

\subsection{Experimental procedure.}

Infrared (IR) spectra (KBr disks, in cm-1) were obtained using a Jasco FT/IR-4600 Fourier Transform spectrometer (Jasco, Tokyo, Japan) or a Shimadzu IR Prestige 21 spectrometer (Shimadzu, Japan). UV spectra were recorded on a Jasco V-550 UV/Vis spectrometer (Jasco, Tokyo, Japan); $\lambda \max (\log \varepsilon)$ in $\mathrm{nm}$. Optical rotations were measured on a Jasco P-2000 polarimeter (Jasco, Tokyo, Japan) with a $1 \mathrm{~cm}$ cell at set temperature. Melting points were obtained on a Buchi melting point B-545 apparatus (Buchi Instrument, Switzerland) without correction. HRESIMS spectra were detected using an Agilent 6210 LC/MSD TOF-MS spectrometer (Agilent Technologies, CA, USA) or a Bruker Apex IV FTMS mass spectrometer. NMR spectra were measured with Bruker AV-600 or AV-500 
spectrometer ( ru er, llanden, witzerland). olumn chromatographies ) were performed on silica gel (300-400 mesh, Qingdao Marine Chemical Plant, China), ODS (Merck, Darmstadt, Germany) and Sephadex LH-20 (Pharmacia, Uppsala, Sweden). Preparative thin layer chromatography (PTLC) separations were carried out $0.50 \mathrm{~mm}$ Yantai (China) silica gel plates. HPLC carried out using Agilent 1260 Series instrument equipped with 1260 series multiple wavelength detector, as well as Cosmosil 5C18-MS-II and chiral Phenomenex Lux cellulose$3(4.6 \times 250 \mathrm{~mm})$ columns. Preparative HPLC carried out using Agilent 1260 Series instrument and Cosmosil 5C18-MS-II $(250 \times 20 \mathrm{~mm} ; 250 \times 10 \mathrm{~mm})$ columns. All solvents used in CC and HPLC were analytical (Tianjin Fuyu Fine Chemical Company, Tianjin, China) and chromatographic grade (Fisher Scientific, NJ, USA), respectively.

\subsection{Phytochemical screening.}

\subsubsection{Selection, authentication and size reduction.}

The Syzygium cumini (L.) Skeels plant was collected in the month of May (Flowering season) from the neighboring village (Nalwar, kalburgi district, Karnataka State, India). The roots were washed thoroughly under running tap water to free them from dust and other contaminants, shade-dried at $20^{\circ} \mathrm{C}$ to remove the moisture content, powdered, and sieved through a muslin cloth, before being used for the extract preparation.

\subsubsection{Extraction.}

The root powder was added with the $500 \mathrm{~mL}$ solvent (which was exhaustively extracted with methanol) and water successively by percolation method, in the Soxhlet apparatus. The extracts obtained were concentrated using rotary flash evaporator (Buchi, Japan) to get the crude residues and the obtained residue was screened for phytochemical analysis as

Tabale-1. extraction results of root powder according to increasing polarity of solvent by maceration process.

\begin{tabular}{l|l|l|l}
$\begin{array}{l}\text { Quantity of powder for } \\
\text { successive extraction } \\
\text { Maceration method }\end{array}$ & $\begin{array}{l}\text { Successive extraction with } \\
\text { increasing polarity of solvent }\end{array}$ & $\begin{array}{l}\text { Extract } \\
\text { Quantity }\end{array}$ & Phytochemical test \\
\hline $100 \mathrm{gm} \mathrm{ScReX} \mathrm{root} \mathrm{powder}$ & Hexane extract & $15 \mathrm{~g}$ & $\begin{array}{l}\text { Multiple spots on TLC all } \\
\text { chemical test positive }\end{array}$ \\
\hline $70 \mathrm{gm} \mathrm{ScReX} \mathrm{root} \mathrm{powder}$ & Methanol extract & $12 \mathrm{~g}$ & $\begin{array}{l}\text { Positive test for alkaloids and } \\
\text { flavonoids }\end{array}$ \\
\hline $50 \mathrm{gm} \mathrm{ScReX} \mathrm{root} \mathrm{powder}$ & Distilled Water extract & $15 \mathrm{~g}$ & Positive test for flavonoids
\end{tabular}

\subsubsection{Qualitative analysis}

Qualitative phytochemical analysis of methanol leaf extract was studied. The tests for various classes of secondary metabolites were as follows.

Alkaloids: $0.2 \mathrm{ml}$ sample was taken and $0.2 \mathrm{ml} \mathrm{HCl}$ was added; 2-3 drops of Dragendroff's reagent added to it, and the appearance of orange or red precipitate and turbid solution indicates the presence of alkaloids.

Carbohydrates: $0.2 \mathrm{ml}$ sample was mixed with few drops of Molisch's reagent ( $\alpha$ - naphthol dissolved in alcohol). $0.2 \mathrm{ml}$ sulphuric acid was added along the sides of the test tube and observed for the appearance of a purple colour ring for a positive test.

Tannins: $0.2 \mathrm{ml}$ plant extract was mixed with $2 \mathrm{ml}$ water and heated on a water bath for 10 minutes. The mixture was filtered and ferric chloride was added to the filtrate and observed for the dark green solution which indicates the presence of tannin. 
Terpenoids: $0.2 \mathrm{ml}$ plant extract was taken in a test tube with $0.2 \mathrm{ml}$ chloroform, and concentrated sulphuric acid was added carefully to form a reddish brown colour at the interface would show the presence of terpenoids.

Glycosides: $0.2 \mathrm{ml}$ sample was mixed with $0.2 \mathrm{ml}$ of chloroform. $0.2 \mathrm{ml}$ of acetic acid was added to this solution and the mixture was cooled on ice. Sulphuric acid was added carefully and the colour change from violet to blue to green indicates the presence of steroidal nucleus (Aglycone portion of glycoside).

Steroids: $0.2 \mathrm{ml}$ sample was mixed with $0.2 \mathrm{ml}$ chloroform, and $0.2 \mathrm{ml}$ concentrated sulphuric acid was added. The appearance of red colour in the lower layer of chloroform indicates the presence of steroids.

Saponins: To $0.5 \mathrm{gm}$ extract, $5 \mathrm{ml}$ distilled water was added in a test tube. The solution was shaken vigorously and observed for a stable persistent froth. The frothing was mixed with 3 drops of olive oil and shaken vigorously after which it was observed for the formation of an emulsion.

Flavonoids: $0.2 \mathrm{ml}$ plant extract was taken in a test tube and mixed with dilute sodium hydroxide solution, before adding diluted hydrochloric acid was. Observation of yellow solution that turns colourless later would indicate the presence of flavonoids.

Mucilage: $0.2 \mathrm{ml}$ extract was taken in a test tube, $0.2 \mathrm{ml}$ absolute alcohol was added, and allowed to try. If the precipitation occurs then mucilage is present.

Volatile oil: $0.2 \mathrm{ml}$ extract was treated with few drops of dilute hydrochloric acid. The appearance of white precipitate indicates the presence of volatile oils (Table 2).

Table 2. Column elution results of activity guided aqueous extract.

\begin{tabular}{l|l|l|l}
$\begin{array}{l}\text { Quantity of aqueous extract } \\
\text { loaded on to column }\end{array}$ & $\begin{array}{l}\text { Solvent in successive isolation } \\
\text { with increasing polarity }\end{array}$ & $\begin{array}{l}\text { Extract } \\
\text { Quantity }\end{array}$ & Phytochemical test \\
\hline $\begin{array}{l}\text { Distilled Water extract } \\
\text { (Aqueous extract) }\end{array}$ & $\begin{array}{l}\text { Hexane } 100 \% \text { and Hxane : } \\
\text { Methanol }(5 \%) \text { increasing ratio } \\
\text { upto Methanol } 100 \%\end{array}$ & $\begin{array}{l}\text { Multiple spots on TLC all } \\
\text { chemical test positive }\end{array}$ \\
\cline { 2 - 4 } & $\begin{array}{l}\text { Methanol with } \\
\text { Methanol:Water }(5 \%) \text { increasing } \\
\text { ratio upto DW } 100 \%\end{array}$ & $\begin{array}{l}\text { Positive test for alkaloids } \\
\text { and flavonoids }\end{array}$ \\
\cline { 2 - 4 } & $\begin{array}{l}\text { Distilled Water extract } 100 \% \\
\text { Positive test for flavonoids } \\
\text { single spots in tlc }\end{array}$
\end{tabular}

\subsubsection{Total Flavonoid Content.}

Total flavonoid was determined by aluminium chloride method as follows: To $100 \mu \mathrm{L}$ extract solution, $300 \mu \mathrm{L}$ Hexane, $100 \mu \mathrm{LAlCl} 3$ (10\%), $100 \mu \mathrm{L} \mathrm{Na}-\mathrm{K}$ tartrate and $300 \mu \mathrm{L}$ distilled water were added sequentially. After $30 \mathrm{~min}$ of incubation, the test solution was vigorously shaken and absorbance was recorded at $415 \mathrm{~nm}$ with a Shimadzu UV-visible spectrophotometer (UV-1800 resolution: $1 \mathrm{~nm}$ ). A standard calibration plot was generated at $415 \mathrm{~nm}$ using a known concentration of quercetin. The concentrations of flavonoid in the test samples were calculated from the calibration plot and expressed as mg quercetin equivalent/g of sample (Table 3).

Table 3. Phytochemical screening results of ScRex AQ and isolated bio-active from macerator and chromatographic columnScReX-1 and synthesis molecule.

\begin{tabular}{|c|c|c|c|c|c|c|c|}
\hline \multirow[t]{2}{*}{ Chemical test } & \multirow{2}{*}{$\begin{array}{l}\text { Crude } \\
\text { extract }\end{array}$} & \multicolumn{5}{|c|}{ Bioactive } & \multirow{2}{*}{$\begin{array}{l}\text { Synthesized } \\
\text { bioactive }\end{array}$} \\
\hline & & Screx-1 & Screx-2 & Screx-3 & Screx-4 & Screx-5 & \\
\hline Alkaloids & +++ & - & + & - & - & - & \\
\hline Carbohydrates & +++ & - & + & - & - & + & \\
\hline Tannins & +++ & - & - & - & + & - & \\
\hline Terpenoids & +++ & - & - & - & - & - & \\
\hline
\end{tabular}




\begin{tabular}{|c|c|c|c|c|c|c|c|}
\hline \multirow[t]{2}{*}{ Chemical test } & \multirow{2}{*}{$\begin{array}{l}\text { Crude } \\
\text { extract }\end{array}$} & \multicolumn{5}{|c|}{ Bioactive } & \multirow{2}{*}{$\begin{array}{l}\text { Synthesized } \\
\text { bioactive }\end{array}$} \\
\hline & & Screx-1 & Screx-2 & Screx-3 & Screx-4 & Screx-5 & \\
\hline Glycosides & +++ & - & - & - & - & - & \\
\hline Steroids & +++ & - & + & - & - & - & \\
\hline Saponins & +++ & - & - & - & - & - & \\
\hline Flavonoids: & +++ & + & - & - & - & - & \\
\hline Mucilage & +++ & - & - & - & - & + & \\
\hline Volatile oil: & +++ & - & - & - & - & - & \\
\hline $\begin{array}{ll}\text { Total } & \text { Flavonoid } \\
\text { Content } & \\
\end{array}$ & +++ & - & - & + & - & - & +++ \\
\hline HPTLC Analysis & +++ & - & - & + & - & - & +++ \\
\hline
\end{tabular}

\subsection{Pharmacological screening of aqueous extract.}

\subsubsection{Toxicological screening of crude extract.}

Acute oral toxicity [33] study was performed as per OECD-423 guidelines (acute toxic class method). Wistar rats $(n=6)$ of either sex selected by random sampling technique were used for the study. The animals were kept fasting for overnight providing only water, after which the extracts (ethyl acetate and methanol) were administered orally at the dose level of 5 $\mathrm{mg} / \mathrm{kg}$ body weight by intragastric tube and observed for 14 days. If mortality was observed in 2 - 3 animals, the dose administered was assigned as toxic dose. If mortality was observed in one animal, the same dose was repeated to confirm the toxic dose. If mortality was not observed, the procedure was repeated for further higher doses such as 50,300 and $2000 \mathrm{mg} / \mathrm{kg}$ body weight.

2.3.2. Screening of Anti-diabetic activity in steptozotocine induced diabetic rate (Experimental induction of diabetes).

Induction of diabetic mellitus: after fasting for $18 \mathrm{~h}, 60$ rats were injected by intraperitoneally with a single dose of $50 \mathrm{mg} / \mathrm{kg}$ streptozotocin after dissolving it in freshly prepared ice-cold citrate buffer ( $\mathrm{pH} 4.5$ ). After the injection, they had free access to feed and water, and were given $5 \%$ glucose solution to drink overnight to counter the hypoglycemic shock. The development of diabetes was confirmed after $48 \mathrm{~h}$ of the streptozotocin injection. The rats having fasting blood glucose level more than $200 \mathrm{mg} / \mathrm{dL}$ were selected for experimentation. Diabetic induced animals divided into seven groups each having 7 animals.

\subsubsection{Collection of blood samples and glucose determination.}

The blood samples were collected by end tail vein cutting method, and the blood glucose level was determined by using one touch electronic glucometer. The group I consisted of 6 normal control animals. The remaining each group consisted of 7 Streptozotocin (STZ) induced diabetic rats. Group I-Normal control animals received 1\% SCMC $10 \mathrm{ml} / \mathrm{kg}$ p o for 15 days; Group II-STZ induced diabetic animals received 1\% SCMC $10 \mathrm{ml} / \mathrm{kg}$, p.o. for 15 days; Group III and IV-STZ induced diabetic animals received ethyl acetate extract at the dose of 200 and $400 \mathrm{mg} / \mathrm{kg}$ p.o. daily for 15 days; Group V and VI- STZ induced diabetic animals received methanolic extract at the dose of 200 and $400 \mathrm{mg} / \mathrm{kg}$ daily p.o. for 15 days; Group VII - STZ induced diabetic animals received mycaminose $50 \mathrm{mg} / \mathrm{kg}$ daily p.o. for 15 Days; Group VIII-STZ induced diabetic animals received standard drug, glibanclamide $1.25 \mathrm{mg} / \mathrm{kg}$ daily p.o. for 15 days. All the group of animals received the treatment by the above schedule for 15 days. The blood samples were collected one hour after drug administration on $1^{\text {st }}, 5^{\text {th }}$, $10^{\text {th }}$, and $15^{\text {th }}$ days to determine the blood glucose level. 


\subsubsection{Statistical analysis.}

The data obtained from pharmacological experiments were expressed as mean \pm SD. Differences between the control and the treatments in these experiments were tested for significance using ANOVA followed by Dunnet's t-test. $\mathrm{p}$ value $<0.05$ were considered as significant.

\subsubsection{Isolation and characterization.}

Five grams of aqueous extract of pure Syzygium cumini (L.) Skeels roots was admixed with $10 \mathrm{~g}$ of silica gel (60 - $120 \mathrm{mesh}$ ), and dried for uniform mixing; the admixture was loaded in a column ( $5 \mathrm{~cm}$ diameter X $50 \mathrm{~cm}$ height) packed with silica gel $(150 \mathrm{~g})$ using hexane as the solvent. The column was eluted with increasing order of polarity gradually from $100 \%$ hexane, $100 \%$ chloroform and methanol in ethyl acetate $(0-100 \%)$. From $100 \%$ methanolic solution, $350 \mathrm{gm}$ of crude extract was obtained. The compound was obtained as white shining crystalline, and the fraction was assessed for phytochemical screening and characterized by spectroscopy techniques like 1H NMR, 13 C NMR and Mass

\subsection{Retro-synthetic strategy.}

The isolated molecule was treated by synthetic strategy [15][20]. All the reagents, starting materials, and solvents were obtained from commercial supplier and were used without further purification. Reactions were carried out in over-dried glassware under a positive pressure of argon unless otherwise mentioned. Air -sensitive reagents and solutions were transferred via syringe or cannula, and were introduced via rubber bungs; reactions were monitored by TLC with $0.25 \mathrm{~mm}$ precoted silica gel plates (60 F254). Visualization was accomplished with UV-light, iodine chamber, or by immersion in ethanolic solution of phosphomolybdic acid (PMA), P-anisaldehyde , or KMnO4. Deuterated solvents for NMR were used as received, and H NMR and C13 NMR spectra were obtained using a 200400 or $500 \mathrm{MHz}$ spectrophotometer. The coupling constant was measured in hertz.

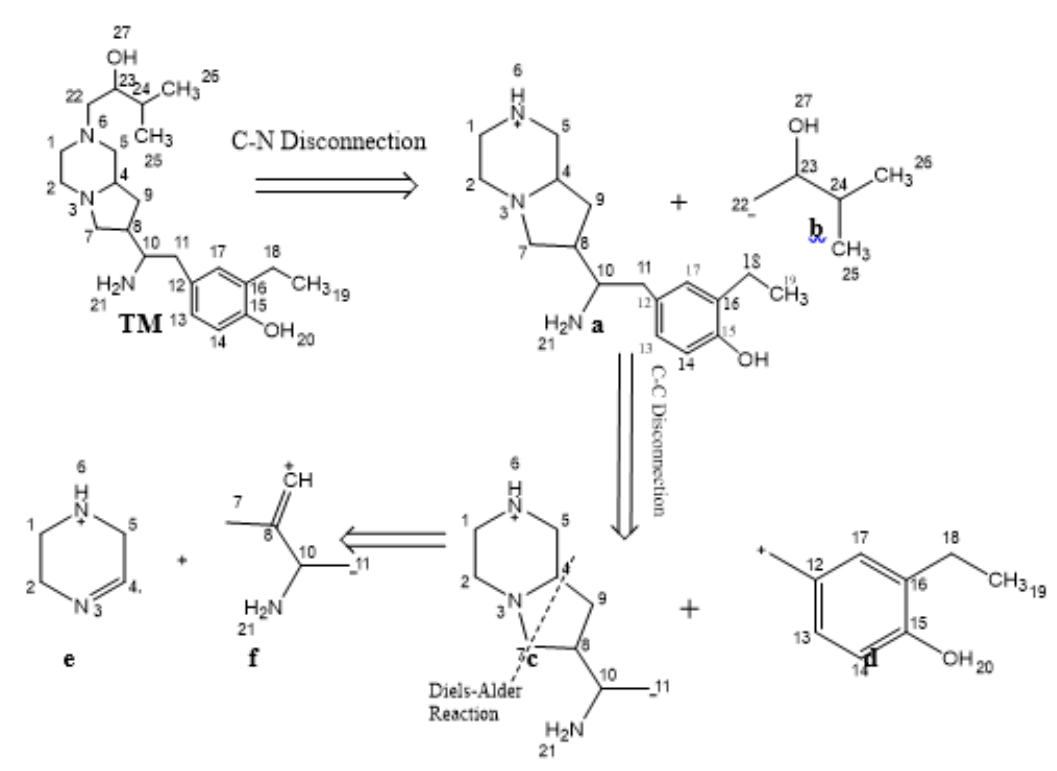

Figure 1. Application of disconnection approach to get the Retroan and Synthon. 


\subsubsection{Selection of molecule for synthesis.}

Based on phytochemical, pharmacological, and spectral assessments, molecule ScReX3 was selected for the total synthesis by adopting sustainable protocol. Chemically, this molecule belongs to the derivatives of piperzine and has active phenolic group in the moieties.

\subsubsection{Scheme-I Disconnection approach on a molecule ScReX-3.}

Backward disconnection was done to get the target molecule (TM), C-N disconnection approach applied on TM to get synthone (A) and retron (B), with generation of (c,d) and (e,f) on $\mathrm{C}-\mathrm{C}$ disconnection; the disconnection analogs in fig 1 explains the characteristic properties of nucleophiles and electrophiles to adopt the reaction and reagent conditions in scheme-II.

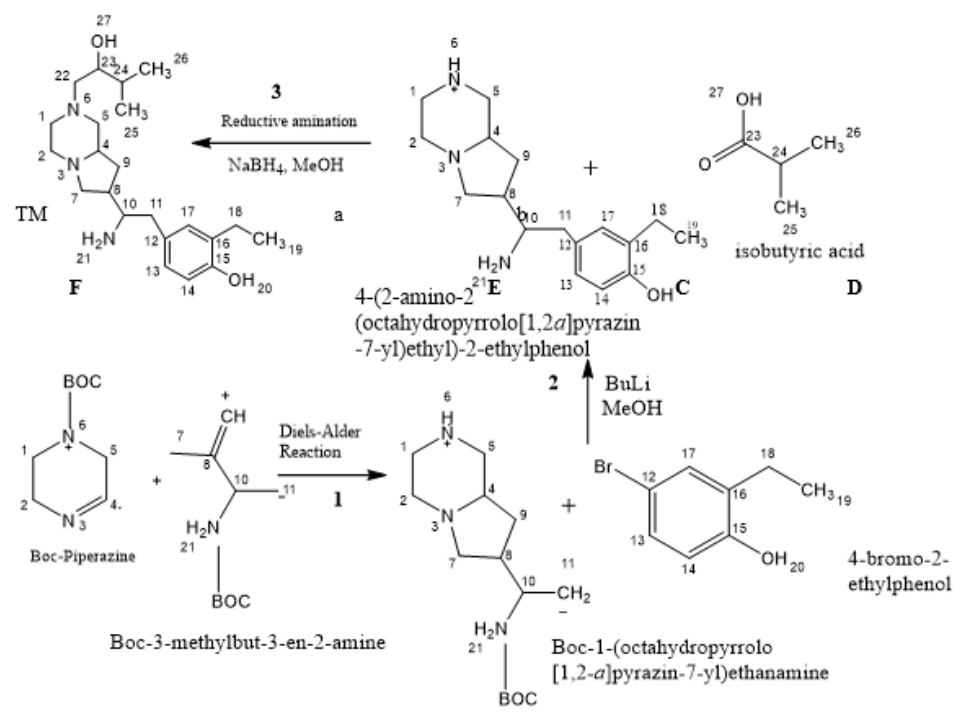

Figure 2. Esigning the synthetic strategy with protecting group.

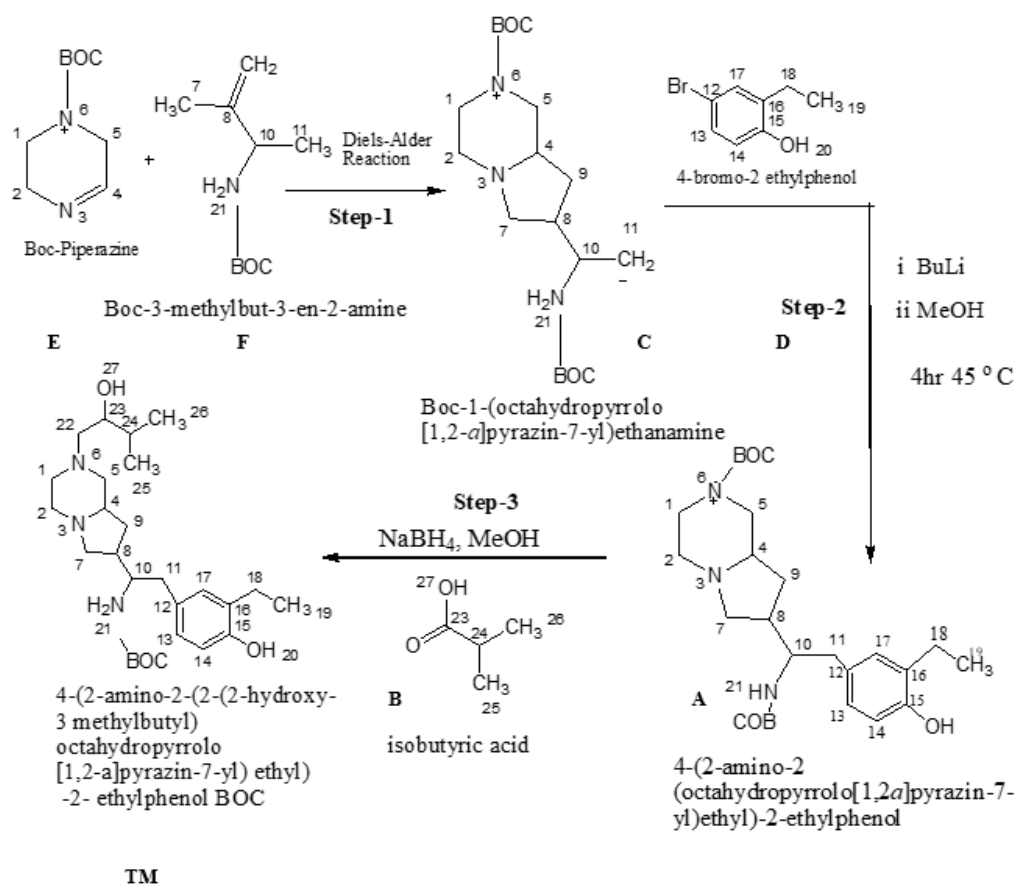

Figure 3. Schematic representation of total synthetic pathway on the basis of the above two schemes. 


\subsubsection{Selection of protecting group.}

The tert-butyloxycarbonyl protecting group or tert-butoxycarbonyl protecting group (BOC group) to protect the $\mathrm{NH}_{2}$ group can be accomplished with strong acids such as $\mathrm{HCl}$ in methanol for removal the BOC to get the molecule.

\subsubsection{Scheme-II: Development of total synthesis}

The initial synthetic root started with piling up the molecule with reaction condition based on the aromaticity; based on the nucleophilic and electrophilic properties of the molecule, BoC was selected as the protecting group wherever required.

\subsubsection{Scheme-III:- Synthetic plan by using simple condensation reaction.}

The initial synthetic root started from Boc protected piperizine by 1, 2-addition of chiral-molecule with aliphatic methyl-butyl amine by adopting dielse alder reaction followed by addition and substitution of ButLi and NaBH4 to get the TM ( target molecule) (Fig 3).

\section{Results and Discussion}

\subsection{Extraction of syzygium cuminii Root powder.}

Hundred grams of shade-dried ScRP (Syzygium cuminii root powder) was utilized for successive maceration, and solvents were used according to the increasing polarity. Three extracts were collected from 100g of ScRP: hexane extract-15gm, methanolic extract-12gm, and aqueous extract-15gm. The TLC monitoring of aqueous extract gave strong positive test for flavonoids with bright visible florescent spot under UV absorption spectroscopy; hence, the aqueous extract was utilized for the isolation of bioactive.

\subsection{Isolation of activity guided extract.}

The aqueous extract, loaded onto the column, the followings are the fraction which were eluted from column with increasing polarity of solvent (Table 2).

\subsection{Phytochemical reports of crude and isolated extract.}

Qualitative analysis of crude and aqueous extract has been monitored to confirm the presence of flavonoide in the extract and isolate to pick-out the molecule in pure form (table $3)$.

\subsection{Total flavonoids description.}

The total flavonoid content has been evaluated to fix the solvent system for Rf value and to assess the solubility of solvent to recrystallize and purify the collected fraction for spectral assessment (table 4).

\subsection{Pharmacological screening of crude extracts.}

Based on pharmacological and phytochemical parameters, ScRex-1 was selected for the assessment of anti-diabetic activity. The blood sugar levels measured in normal and experimental rats are given in Table 4. The streptozotocin-induced diabetic rats showed 
significant increase in blood sugar level, compared to normal rats. The oral administration of aqueous and methanol extracts (200 and $400 \mathrm{mg} / \mathrm{kg}$ ) showed significant decrease $(\mathrm{p}<0.05)$ in blood sugar level. The isolated compound, ScReX AQ RE at a dose level of $50 \mathrm{mg} / \mathrm{kg}$ also showed significant decrease $(\mathrm{p}<0.05)$ in blood sugar level. The standard drug, glibenclamide decreased blood sugar level in 15 days treatment (Table 4).

Table 4. Solvent system, extract preparation, detecting reagent and visualization for HPTLC.

\begin{tabular}{|c|c|c|c|c|c|}
\hline Class & Solvent system & Extract preparation & Reagent & $\begin{array}{l}\text { Visualization } \\
\text { wavelength }\end{array}$ & Color \\
\hline Flavonoid & $\begin{array}{l}\text { Ethyl acetate: formic } \\
\text { acid: glacial acetic acid: } \\
\text { water }(10: 0.5: 0.5: 1.3)\end{array}$ & $\begin{array}{l}\text { Powdered drug }(1 \mathrm{gm}) \text { in } 5 \mathrm{ml} \\
\text { methanol was extracted by heating } \\
\text { on a water bath for } 10 \\
\text { min }\end{array}$ & $\begin{array}{l}\text { Anisaldehyde } \\
\text { sulphuric acid }\end{array}$ & 365 & Blue \\
\hline $\begin{array}{l}\text { Anthragly } \\
\text { cosides }\end{array}$ & $\begin{array}{l}\text { Ethyl acetate: methanol: } \\
\text { water }(100: 13.5: 10)\end{array}$ & $\begin{array}{l}\text { Powdered drug }(1 \mathrm{gm}) \text { in } 5 \mathrm{ml} \\
\text { methanol was extracted by heating } \\
\text { on water bath for } 10 \mathrm{~min}\end{array}$ & $10 \% \mathrm{KOH}$ & Visible & Red, yellow \\
\hline $\begin{array}{l}\text { Bitter } \\
\text { Principle }\end{array}$ & $\begin{array}{l}\text { Ethyl acetate: methanol: } \\
\text { Water }(100: 13.5: 10)\end{array}$ & $\begin{array}{l}\text { Powdered drug }(1 \mathrm{gm}) \text { in } 5 \mathrm{ml} \\
\text { methanol was extracted by heating } \\
\text { on water bath for } 10 \mathrm{~min}\end{array}$ & $\begin{array}{l}\text { Vanillin } \\
\text { sulphuric acid }\end{array}$ & Visible & $\begin{array}{l}\text { Red, violet, } \\
\text { yellow, blue } \\
\text { brown, green }\end{array}$ \\
\hline Saponin & $\begin{array}{l}\text { Chloroform: acetic acid: } \\
\text { methanol: } \quad \text { water } \\
(6.4: 3.2: 1.2: 0.8)\end{array}$ & $\begin{array}{l}\text { Above extract prepared, filtered and } \\
\text { evaporated to } 1 \mathrm{ml} \text {, mixed with } 0.5 \\
\mathrm{ml} \text { water and extracted with } 3 \mathrm{ml} \text { of } \\
\mathrm{n} \text {-butanol }\end{array}$ & $\begin{array}{l}\text { Vanillin } \\
\text { sulphuric acid }\end{array}$ & Visible & $\begin{array}{l}\text { Blue, blue } \\
\text { violet, yellow } \\
\text {, red brown }\end{array}$ \\
\hline Triterpenes & $\begin{array}{l}\text { Chloroform: methanol } \\
(9.5: 0.5)\end{array}$ & $\begin{array}{l}\text { Powdered drug (1gm) was extracted } \\
\text { by heating under reflux for } 15 \mathrm{~min} \\
\text { with } 10 \mathrm{ml} \\
\text { dichloromethane }\end{array}$ & $\begin{array}{l}\text { Anisaldehyde } \\
\text { sulphuric acid }\end{array}$ & Visible & $\begin{array}{l}\text { Blue violet, } \\
\text { red to red } \\
\text { violet }\end{array}$ \\
\hline $\begin{array}{l}\text { Phenol } \\
\text { carboxylic } \\
\text { acid }\end{array}$ & $\begin{array}{l}\text { n-butanol: acetic acid: } \\
\text { Carboxylic acid: water } \\
(4: 1: 1)\end{array}$ & $\begin{array}{l}\text { Powdered drug }(1 \mathrm{gm}) \text { was extracted } \\
\text { by heating under reflux for } 15 \mathrm{~min} \\
\text { with } 10 \mathrm{ml} \\
\text { dichloromethane }\end{array}$ & $\mathrm{FeCl} 3$ & Visible & $\begin{array}{l}\text { Brown, grey, } \\
\text { black }\end{array}$ \\
\hline Coumarin & $\begin{array}{l}\text { Toluene: ethyl acetate } \\
(93: 7)\end{array}$ & $\begin{array}{l}\text { Powdered drug }(1 \mathrm{gm}) \text { was extracted } \\
\text { by heating under reflux for } 15 \mathrm{~min} \\
\text { with } 10 \mathrm{ml} \\
\text { dichloromethane }\end{array}$ & $10 \% \mathrm{KOH}$ & 365 & $\begin{array}{l}\text { Light blue, } \\
\text { brown }\end{array}$ \\
\hline Essential oil & $\begin{array}{l}\text { Toluene: ethyl acetate } \\
(93: 7)\end{array}$ & $\begin{array}{l}\text { Powdered drug }(1 \mathrm{gm}) \text { was extracted } \\
\text { by heating under reflux for } 15 \mathrm{~min} \\
\text { with } 10 \mathrm{ml} \\
\text { dichloromethane }\end{array}$ & $\begin{array}{l}\text { Vanillin } \\
\text { sulphuric acid }\end{array}$ & Visible & $\begin{array}{l}\text { Red, yellow, } \\
\text { blue, brown, } \\
\text { green }\end{array}$ \\
\hline Alkaloids & $\begin{array}{l}\text { Toluene: ethyl acetate: } \\
\text { diethyl amine }(7: 2: 1)\end{array}$ & $\begin{array}{l}\text { Powdered drug (1gm) was } \\
\text { moistened with } 1 \mathrm{ml}, 10 \% \text { ammonia } \\
\text { solution on water bath }\end{array}$ & $\begin{array}{l}\text { Dragendroff's } \\
\text { Reagent }\end{array}$ & Visible & Orange brown \\
\hline
\end{tabular}

Table 5. Anti-diabetic activity of Syzygium cumini root extracts against Streptozotocin -induced diabetic rats. \begin{tabular}{l|l|c} 
Group (15 days) & \multicolumn{2}{|c}{ Blood sugar level in $\mathrm{mg} / \mathrm{dL}$ (mean \pm SD) }
\end{tabular}

\begin{tabular}{|c|c|c|c|c|c|}
\hline \multirow{2}{*}{ Group (15 days) } & \multicolumn{5}{|c|}{ Blood sugar level in mg/dL $($ mean \pm SD) } \\
\hline & Initial & Day 1 & Day 5 & Day 10 & Day 15 \\
\hline Group - I $(n=6)$ & $70.78 \pm 7.03$ & $64.04 \pm 9.33$ & $66.70 \pm 9.85$ & $67.00 \pm 7.41$ & $65.48 \pm 5.88$ \\
\hline Group - II $(n=5)$ & $249.76 \pm 8.85$ & $262.28 \pm 14.75$ & $285.85 \pm 4.78$ & $309.20 \pm 8.09$ & $313.28 \pm 4.73$ \\
\hline Group - III $(\mathrm{n}=6)$ & $250.85 \pm 8.40$ & $252.49 \pm 5.57 \mathrm{a}^{\mathrm{NS}}$ & $239.23 \pm 8.42 \mathrm{a}^{\mathrm{NS}} \mathrm{b}^{*}$ & $204.38 \pm 5.84 \mathrm{a}^{*} \mathrm{~b} *$ & $192.03 \pm 5.80 \mathrm{a}^{*} \mathrm{~b}^{*}$ \\
\hline Group - IV (n=7) & $249.04 \pm 3.89$ & $249.65 \pm 7.85 \mathrm{aNS}$ & $221.24 \pm 5.41 \mathrm{a}^{*} \mathrm{~b}^{*}$ & $189.10 \pm 8.22 \mathrm{a}^{*} \mathrm{~b} *$ & $178.14 \pm 9.30 \mathrm{a}^{*} \mathrm{~b}^{*}$ \\
\hline Group - V (n=6) & $248.70 \pm 8.85$ & $256.08 \pm 4.98 \mathrm{aNS}$ & $239.88 \pm 8.84 \mathrm{a}^{\mathrm{NS}} \mathrm{b}^{*}$ & $214.23 \pm 3.33 a^{*} b^{*}$ & $182.85 \pm 4.58 \mathrm{a}^{*} \mathrm{~b}^{*}$ \\
\hline Group - VI $(\mathrm{n}=7)$ & $251.84 \pm 4.90$ & $256.57 \pm 5.57 \mathrm{aNS}$ & $233.45 \pm 6.30 \mathrm{a}^{*} \mathrm{~b}^{*}$ & $192.77 \pm 4.89 \mathrm{a}^{*} \mathrm{~b} *$ & $154.85 \pm 10.24 a^{*} b^{*}$ \\
\hline Group - VII (n=7) & $248.38 \pm 3.50$ & $251.17 \pm 8.14 \mathrm{aNS}$ & $217.97 \pm 4.52 \mathrm{a}^{*} \mathrm{~b}^{*}$ & $190.10 \pm 7.91 \mathrm{a}^{*} \mathrm{~b}^{*}$ & $180.21 \pm 8.68 \mathrm{a}^{*} \mathrm{~b}^{*}$ \\
\hline Group - VIII $(n=7)$ & $249.62 \pm 8.53$ & $247.51 \pm 8.11 \mathrm{aNS}$ & $190.07 \pm 11.04 \mathrm{a}^{*} \mathrm{~b}^{*}$ & $167.84 \pm 9.37 \mathrm{a}^{*} \mathrm{~b} *$ & $123.93 \pm 5.89 \mathrm{a}^{*} \mathrm{~b}^{*}$ \\
\hline
\end{tabular}

\subsection{Pharmacological screening of ScReX-1.}

The blood sugar levels measured in normal and experimental rats are given in Table 3. The streptozotocin-induced diabetic rats showed a significant increase in the levels of blood sugar as compared to normal rats. Oral administration of ScReX-1 isolated molecule at (200 and $400 \mathrm{mg} / \mathrm{kg}$ ) showed significant decrease $(\mathrm{p}<0.05)$ in blood sugar level. The isolated compound, ScRex-1 at a dose level of $50 \mathrm{mg} / \mathrm{kg}$ also showed a significant decrease $(\mathrm{p}<0.05)$ in blood sugar level. The standard drug, glibenclamide, decreased blood sugar level in 15 days 
treatment. Based on the above parameters, it was observed that ScRex-1belongs to the family of flavonides, and gives strong positive test for flovonides, as shown in the table (Table 6).

Table 6. Anti-diabetic activity of ScReX-1 molecule against Streptozotocin -induced diabetic rats.

\begin{tabular}{|c|c|c|c|c|c|}
\hline \multirow[t]{2}{*}{ Group (15 days) } & \multicolumn{5}{|c|}{ Blood sugar level in $\mathrm{mg} / \mathrm{dL}($ mean $\pm \mathrm{SD})$} \\
\hline & Initial & Day 1 & Day 5 & Day 10 & Day 15 \\
\hline Group $-I \quad(n=6)$ & $60.78 \pm 7.03$ & $64.04 \pm 9.33$ & $65.70 \pm 9.85$ & $66.00 \pm 7.41$ & $65.48 \pm 5.88$ \\
\hline Group - II $(n=5)$ & $239.76 \pm 8.85$ & $252.28 \pm 14.75$ & $265.85 \pm 4.78$ & $209.20 \pm 8.09$ & $213.28 \pm 4.73$ \\
\hline Group - III $(n=6)$ & $240.85 \pm 8.40$ & $242.49 \pm 5.57 \mathrm{a}^{\mathrm{NS}}$ & $229.23 \pm 6.42 \mathrm{a}^{\mathrm{NS}} \mathrm{b}^{*}$ & $200.38 \pm 5.84 a^{*} b^{*}$ & $182.03 \pm 4.80 \mathrm{a}^{*} \mathrm{~b} *$ \\
\hline Group - IV $(n=7)$ & $239.04 \pm 3.89$ & $240.65 \pm 7.85 \mathrm{aNS}$ & $220.24 \pm 4.41 \mathrm{a}^{*} \mathrm{~b}^{*}$ & $189.10 \pm 8.22 \mathrm{a}^{*} \mathrm{~b}^{*}$ & $168.14 \pm 8.30 \mathrm{a}^{*} \mathrm{~b}^{*}$ \\
\hline Group $-V(n=6)$ & $238.70 \pm 8.85$ & $231.08 \pm 4.98 \mathrm{aNS}$ & $229.88 \pm 8.84 \mathrm{a}^{\mathrm{NS}} \mathrm{b}^{*}$ & $200.23 \pm 3.33 \mathrm{a}^{*} \mathrm{~b}^{*}$ & $152.85 \pm 3.58 \mathrm{a}^{*} \mathrm{~b}^{*}$ \\
\hline Group - VI $(n=7)$ & $241.84 \pm 4.90$ & $246.57 \pm 5.57 \mathrm{aNS}$ & $223.45 \pm 6.30 a^{*} b^{*}$ & $182.77 \pm 4.89 \mathrm{a}^{*} \mathrm{~b}^{*}$ & $134.85 \pm 9.24 \mathrm{a}^{*} \mathrm{~b}^{*}$ \\
\hline Group - VII $(n=7)$ & $238.38 \pm 3.50$ & $241.17 \pm 8.14 \mathrm{aNS}$ & $210.97 \pm 4.52 \mathrm{a} * \mathrm{~b} *$ & $180.10 \pm 7.91 \mathrm{a}^{*} \mathrm{~b} *$ & $130.21 \pm 7.68 \mathrm{a} * \mathrm{~b}^{*}$ \\
\hline Group - VIII $(n=7)$ & $229.62 \pm 8.53$ & $237.51 \pm 8.11 \mathrm{aNS}$ & $170.07 \pm 11.04 \mathrm{a}^{*} \mathrm{~b}^{*}$ & $157.84 \pm 9.37 \mathrm{a} * \mathrm{~b}^{*}$ & $120.93 \pm 4.89 \mathrm{a} * \mathrm{~b} *$ \\
\hline
\end{tabular}

Values are mean \pm SD of respective groups, NS -Non Significant, $*_{\mathrm{p}}^{\mathrm{p}<0.05}$ Comparison were made a - Initial Vs day 1 , day 5, day 10 and day 15 of respective groups b-Group II Vs group III, IV, V, VI, VII and VIII

\subsection{Characterization and selection of bioactive for total synthesis.}

Chemical analysis of the collected fractions has been critically assessed, to get the chemical description, to design the synthetic strategy. the followings are the chemical parameters given in table 7 .

Table 7. Results of Spectroscopic characterization.

\begin{tabular}{l|l}
$\begin{array}{c}\text { S. Code Rf- } \\
\text { Value }\end{array}$ & \multicolumn{1}{c}{ Chemical name } \\
\hline $\begin{array}{l}\text { ScReX-1 } \\
10.48 \mathrm{mg}\end{array}$ & $\begin{array}{l}\text { 4-(2-amino-2-(2-(2-hydroxy-3 methylbutyl) octahydropyrrolo [1,2-a]pyrazin-7-yl) ethyl) -2- } \\
\text { ethylphenol }\end{array}$ \\
\hline ScReX-2 0.4mg & $\begin{array}{l}\text { 9-((2-hydroxy-5-m-tolylpentan-2-yloxy)methyl)-2,10-dimethoxyicosahydro-1H-phenanthro[2,1- } \\
\text { f]chromene-1,9-diol }\end{array}$ \\
\hline $\begin{array}{l}\text { ScReX-3 } \\
\mathbf{0 . 6 2 m g}\end{array}$ & $\begin{array}{l}\text { (E)-1-(3-aminophenyl)-7-hydroxy-6-methoxy-3-methyl-7-(1,3,11-trimethoxy-2,4,4,13,14- } \\
\text { pentamethyl-2,3,4,7,8,9,10,11,12,13,14,15,16,17-tetradecahydro-1H-cyclopenta[a]phenanthren-17- }\end{array}$ \\
\hline $\begin{array}{l}\text { ScReX-4 } \\
\mathbf{0 . 5 0} \mathbf{~ m g}\end{array}$ & $\begin{array}{l}\text { 6-(6-acetyl-2-(11-acetyl-8a-(1-aminoethyl)-4,4,6a,6b,11-pentamethyl-14-oxo 1,2,3,4,4a, } \\
\text { 5,6,6a,6b,7,8,8a,9,10,11,12,12a,14,14a,14b-icosahydropicen-3-yloxy)-4,5-dihydroxy tetrahydro-2H- } \\
\text { pyran-3-yloxy)-3,4,5-trihydroxytetrahydro-2H-pyran-2-carboxylic acid }\end{array}$ \\
\hline $\begin{array}{l}\text { ScReX-5 } \\
\mathbf{0 . 5} \mathbf{~ m g}\end{array}$ & $\begin{array}{l}\text { 14-hydroxy-11-methoxy-10-(2-methoxypropoxy)-4,6a,6b,12,14b-pentamethyl-8a-(methylamino)-4- } \\
\text { (1-(2,4,8-trimethyl-2,5,6,7,8,8a-hexahydro-1H-pyrido[3,4-d][1,3]oxazin-6- } \\
\text { yloxy)ethyl)octadecahydro-1H-phenanthro[1,2-h]isochromen-3(4H)-one }\end{array}$ \\
\hline ScReX-6 0.5mg & $\begin{array}{l}\text { 6-(17-(4,6-dihydroxy-5-methoxy-2-(methylperoxy)tetrahydro-2H-pyran-3-yloxy)-1,12-dimethoxy- } \\
\text { 4,5,8,10,12,13,14,17-octahydro-1H-cyclopenta[a]phenanthren-3-yloxy)-2-(methylperoxy)-3,4- } \\
\text { dihydro-2H-pyran-3,4,5-triol. }\end{array}$
\end{tabular}

\subsection{Chromatographic, Spectroscopic and spectrophotometric analysis of TM.}

The target molecule (ScReX-1) chemically designated as 4-(2-amino-2-(2-(2-hydroxy3 methylbutyl) octahydropyrrolo [1,2-a] pyrazin-7-yl) ethyl) -2- ethylphenol. The molecular formula was $\mathrm{C}_{22} \mathrm{H}_{37} \mathrm{~N}_{3} \mathrm{O}_{2}$, melting point around $302^{\circ} \mathrm{C}$, the molecular weight 375 , and $\mathrm{UV}$ spectroscopy in methanol showed $\lambda_{\max }$ as 235 . It was white crystalline powder soluble in methanol and DMSO.

\subsection{Chemical and analytical properties of TM.}

The molecule contains alcoholic functionality, and more than one aromatic ring are fused with the diazine hetroaromatic structures. The parent hydride of the compound was 
hetero-aromatic with characteristic alcohol and Benzene. The functionalized hydride was phenol (Fig 4).

Fig 4: Chemical properties of the Target Molecule selected for total synthesis represented in Scheme-III The substituents attached to the cyclic hetero aromatic were at the $4^{\text {th }}$ position, 2-[2-(2-hydroxy-3-methylbutyl and 2-amino on position $3^{\text {rd }}$ and 2 perhydropyrrolol [1, 2-a] pyrazin-7-yl, 2-ethylphenol (TM). Once the reaction was complete, the reaction mixture was allowed cooled to room temperature and filtered to obtain the crystals of the final product. All compounds were fully characterized by mp, IR, 1H NMR and 13C NMR spectroscopy monitored as follows.

Yield 78\%, m.p. 221-230 ${ }^{\circ} \mathrm{C}$, IR (KBr; cm-1): 3441 (N-H str.), 3110 (Ar.C-H str.), 2917 (Ali. CH str.) 1635 (Carbon. str.), 1472 (Ar C-C. str.), 1462 (Ar C-C. str.), 1378 (R-NH2 str.); HR-ESIMS ([M_ $\left.]_{-}^{-} \mathrm{m} / \mathrm{z}\right): 375(12 \%)$ peak $\left(\mathrm{C}_{22} \mathrm{H}_{37} \mathrm{~N}_{3} \mathrm{O}_{2}\right), 324(12 \%)$ peak $\left(-\mathrm{C}_{4} \mathrm{H}_{6} \mathrm{O}^{-+}\right), 309$ $(12 \%)$ peak $\left(\mathrm{C}_{18} \mathrm{H}_{35} \mathrm{~N}_{3} \mathrm{O}\right)$, and $255(25 \%)\left(-\mathrm{C}_{4} \mathrm{H}_{5} \mathrm{O}^{-+}\right)$; 13C NMR (62.9 MHz, CDCl3): C,-C$\mathrm{R}$ groups of $1-\beta-\mathrm{CH}_{3}$ proton(s), $\delta 0.82$ to $\delta 0.88$ (3 Hz $8 \mathrm{H} \mathrm{J}$ ), $\delta 2.56 \delta 2.69-\mathrm{C}$, $-\mathrm{N}$, $-\mathrm{N}(\mathrm{C}) \mathrm{C}$, O-C groups of 1- $\alpha, \beta-\mathrm{CH}_{2}$ pyrrolidine $\mathrm{CH}, \mathrm{CH}_{2}$ proton(s) $(8 \mathrm{~Hz} 18 \mathrm{H} \mathrm{J})$, and $\delta 3.34 \mathrm{C}-\mathrm{OH}$ aromatic $\mathrm{C}-\mathrm{OH}$ proton(s) $(6 \mathrm{~Hz} 20 \mathrm{H} \mathrm{J}) \delta 7.63-\mathrm{O},-\mathrm{CC}$, 1-benzene of aromatic proton(s) 1.50 $\mathrm{Hz} 9 \mathrm{H}$; Rf-0.62, single spot in solvent system of EtOAc:methanol:water 4:5:1TM (Fig. 4 Scheme 3).

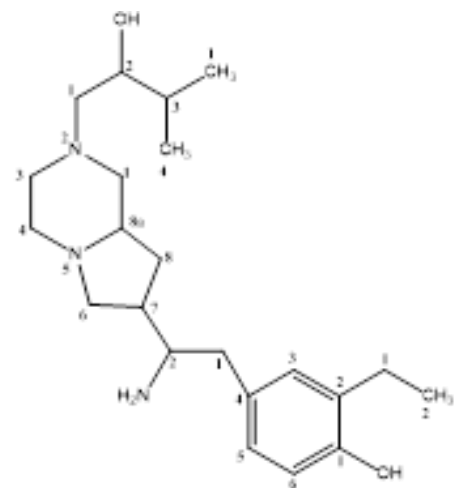

Figure 4. Chemical properties of the Target Molecule selected for total synthesis represented in Scheme-III.

\subsubsection{Step-1: Boc-1-(octahydropyrrolo [1,2-a]pyrazin-7 yl)ethanamine.}

Once the reaction was complete, the reaction mixture was allowed cooled to room temperature and filtered to obtain the crystals of final product. The obtained Product in white crystalline form C (Fig 5 ) monitored for mp, IR, HR-ESIMS and 13C NMR spectroscopy. Yield 78\%, m.p. 231-235 ${ }^{\circ} \mathrm{C}$, IR (KBr; cm-1): 3341 (N-H str.), 3120 (Ar.C-H str.), 2817 (Ali. CH str.) 1655 (Carbon. str.), 141 (Ar C-C. str.), 1457 (Ar C-C. str.), 1364 (R-NH2 str.); HRESIMS ([M $\left.\left.\_\mathrm{H}\right]^{-} \mathrm{m} / z\right): 375(12 \%)$ peak $\left(\mathrm{C}_{22} \mathrm{H}_{37} \mathrm{~N}_{3} \mathrm{O}_{2}\right), 324(12 \%)$ peak $\left(-\mathrm{C}_{4} \mathrm{H}_{6} \mathrm{O}^{-+}\right), 309(12$ $\%)$ peak $\left(\mathrm{C}_{18} \mathrm{H}_{35} \mathrm{~N}_{3} \mathrm{O}\right)$, and $255(25 \%)\left(-\mathrm{C}_{4} \mathrm{H}_{5} \mathrm{O}^{-+}\right)$; 13C NMR (62.9 MHz, CDCl3): C,-C-R groups of $1-\beta-\mathrm{CH}_{3}$ proton(s), $\delta 0.82$ to $\delta 0.88(3 \mathrm{~Hz} 8 \mathrm{H} \mathrm{J}), \delta 2.56 \delta 2.69-\mathrm{C},-\mathrm{N},-\mathrm{N}(\mathrm{C}) \mathrm{C},-\mathrm{O}-$ $\mathrm{C}$ groups of $1-\alpha, \beta-\mathrm{CH}_{2}$ pyrrolidine $\mathrm{CH}, \mathrm{CH}_{2}$ proton(s) $(8 \mathrm{~Hz} 18 \mathrm{H} \mathrm{J})$, and $\delta 3.34 \mathrm{C}-\mathrm{OH}$ aromatic $\mathrm{C}-\mathrm{OH}$ proton(s) $(6 \mathrm{~Hz} 20 \mathrm{H} \mathrm{J}) \delta 7.63-\mathrm{O},-\mathrm{CC}, 1$-benzene of aromatic proton(s) 1.50 $\mathrm{Hz} 9 \mathrm{H}$; Rf-0.42, single spot in solvent system of EtOAc:methanol:water 4:5:1, molecule C (Fig 5 Scheme 3). 


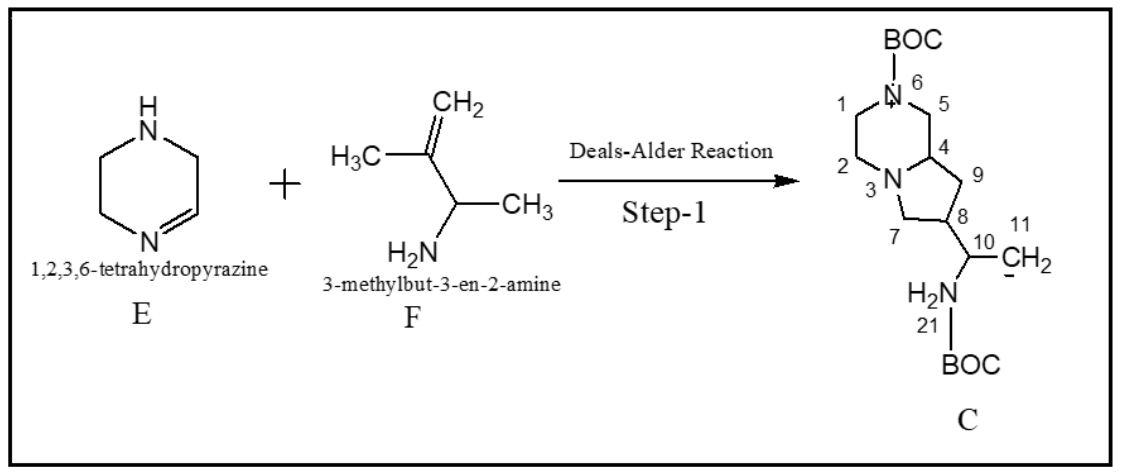

Figure 5. Spectral assessment of BOC protected retron.

3.9.2. Step-2:- 4-(2-amino-2(octahydropyrrolo[1,2a]pyrazin-7-yl)ethyl)-2-ethylphenol.

Once the reaction was complete, the reaction mixture was allowed cooled to room temperature and filtered to obtain the crystals of final product. The obtained Product in white crystalline form E (Fig 6 ) monitored for mp, IR, HR-ESIMS and 13C NMR spectroscopy.

Yield 78\%, m.p. 231-235 ${ }^{\circ} \mathrm{C}$, IR (KBr; cm-1): 3341 (N-H str.), 3120 (Ar.C-H str.), 2817 (Ali. CH str.) 1655 (Carbon. str.), 141 (Ar C-C. str.), 1457 (Ar C-C. str.), 1364 (R-NH2 str.); HRESIMS ([M $\left.-\mathrm{H}]^{-} \mathrm{m} / z\right): 375(12 \%)$ peak $\left(\mathrm{C}_{22} \mathrm{H}_{37} \mathrm{~N}_{3} \mathrm{O}_{2}\right), 324(12 \%)$ peak $\left(-\mathrm{C}_{4} \mathrm{H}_{6} \mathrm{O}^{-+}\right), 309(12$ $\%)$ peak $\left(\mathrm{C}_{18} \mathrm{H}_{35} \mathrm{~N}_{3} \mathrm{O}\right)$, and $255(25 \%)\left(-\mathrm{C}_{4} \mathrm{H}_{5} \mathrm{O}^{-+}\right)$; 13C NMR (62.9 MHz, CDCl3): C,-C-R groups of $1-\beta-\mathrm{CH}_{3}$ proton(s), $\delta 0.82$ to $\delta 0.88(3 \mathrm{~Hz} 8 \mathrm{H} J), \delta 2.56 \delta 2.69-\mathrm{C},-\mathrm{N},-\mathrm{N}(\mathrm{C}) \mathrm{C}$, -O$\mathrm{C}$ groups of $1-\alpha, \beta-\mathrm{CH}_{2}$ pyrrolidine $\mathrm{CH}, \mathrm{CH}_{2}$ proton(s) $(8 \mathrm{~Hz} 18 \mathrm{H} \mathrm{J})$, and $\delta 3.34 \mathrm{C}-\mathrm{OH}$ aromatic $\mathrm{C}-\mathrm{OH}$ proton(s) $(6 \mathrm{~Hz} 20 \mathrm{H} \mathrm{J}) \delta 7.63-\mathrm{O},-\mathrm{CC}$, 1-benzene of aromatic proton(s) 1.50 $\mathrm{Hz} 9 \mathrm{H}$; Rf-0.42, single spot in solvent system of EtOAc:methanol:water 4:5:1, molecule C (Fig 6 Scheme3).

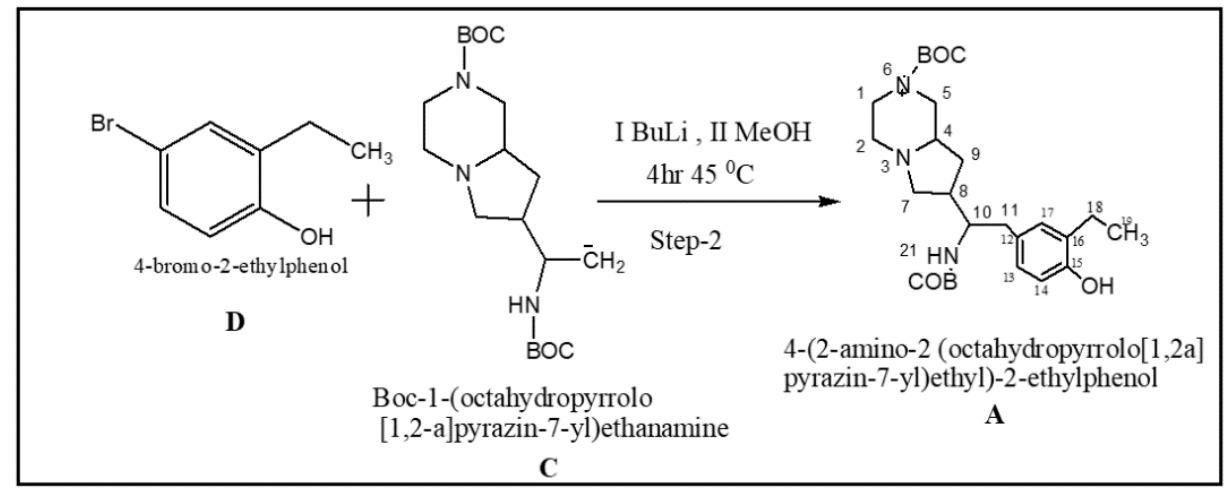

Figure 6. Spectral assessment of BOC protected syntho.

3.9.3. Step-3:-4-(2-amino-2-(2-(2-hydroxy-3-methylbutyl) octahydropyrrolo-[1,2-a]pyrazin-7yl) ethyl)-2-ethylphenol BOC.

Once the reaction was complete, the reaction mixture was allowed cooled to room temperature and filtered to obtain the crystals of final product. The obtained Product in white crystalline form E (Fig 7) monitored for mp, IR, HR-ESIMS and 13C NMR spectroscopy.

Yield 78\%, m.p. 221-230 ${ }^{\circ} \mathrm{C}$, IR (KBr; cm-1): 3441 (N-H str.), 3110 (Ar.C-H str.), 2917 (Ali. CH str.) 1635 (Carbon. str.), 1472 (Ar C-C. str.), 1462 (Ar C-C. str.), 1378 (R-NH2 str.); HRESIMS ([M_H $\left.]^{-} \mathrm{m} / z\right): 375(12 \%)$ peak $\left(\mathrm{C}_{22} \mathrm{H}_{37} \mathrm{~N}_{3} \mathrm{O}_{2}\right), 324(12 \%)$ peak $\left(-\mathrm{C}_{4} \mathrm{H}_{6} \mathrm{O}^{-+}\right), 309(12$ $\%)$ peak $\left(\mathrm{C}_{18} \mathrm{H}_{35} \mathrm{~N}_{3} \mathrm{O}\right)$, and $255(25 \%)\left(-\mathrm{C}_{4} \mathrm{H}_{5} \mathrm{O}^{-+}\right)$; 13C NMR (62.9 MHz, CDCl3): C,-C-R groups of $1-\beta-\mathrm{CH}_{3}$ proton(s), $\delta 0.82$ to $\delta 0.88(3 \mathrm{~Hz} 8 \mathrm{H} J), \delta 2.56 \delta 2.69-\mathrm{C},-\mathrm{N},-\mathrm{N}(\mathrm{C}) \mathrm{C}$, -O- 
$\mathrm{C}$ groups of $1-\alpha, \beta-\mathrm{CH}_{2}$ pyrrolidine $\mathrm{CH}, \mathrm{CH}_{2}$ proton(s) $(8 \mathrm{~Hz} 18 \mathrm{H} \mathrm{J})$, and $\delta 3.34 \mathrm{C}-\mathrm{OH}$ aromatic $\mathrm{C}-\mathrm{OH}$ proton(s) $(6 \mathrm{~Hz} 20 \mathrm{H} \mathrm{J}) \delta 7.63-\mathrm{O},-\mathrm{CC}, 1$-benzene of aromatic proton(s) 1.50 $\mathrm{Hz} 9 \mathrm{H}$; Rf-0.62, single spot in solvent system of EtOAc :methanol :water 4:5:1TM (Fig 7 Scheme 3).

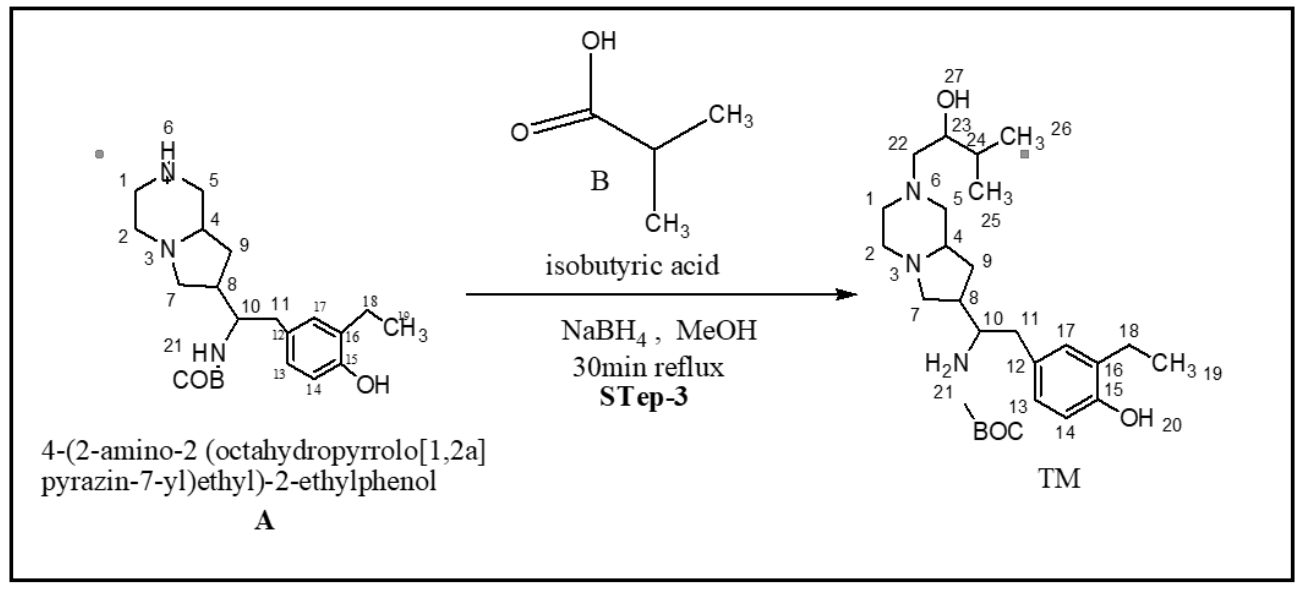

Figure 7. Spectral assessment of BOC protected synthesized structure.

\subsection{Discussion.}

The primary objective of the study was to select the root part of the Syzygium cuminii ( L) skeel, which is the first time approach in the research on this plant. It was quite challenging but has proved that the root part of any medicinal plant is an important source of bioactive. The second objective of the study was to maintain the sustainable approach to collect the extract from the root powder and to screen it for antidiabetic activity, which showed strong and potent reduction of blood glucose level in steptozotocine induced diabetic rat model (dose levels of 200,300 , and $400 \mathrm{mg} / \mathrm{kg}$ of aqueous extract in 15 days). This is the highest reduction of blood glucose level compared to the Glibincalamide standard anti-diabetic drug. Since the plant has food value, it did not show toxicity at $2000 \mathrm{mg} / \mathrm{kg}$ dose in the animal model. Lastly, this study collected the biomolecule responsible for antidiabetic activity on the basis of phytochemical, pharmacological, and analytical characterizations, designated as 4-(2-amino-2-(2-(2-hydroxy3 methylbutyl) octahydropyrrolo [1,2-a] pyrazin-7-yl) ethyl) -2- ethylphenol (ScReX-I); the total synthesis was successful.

According to the previous findings, the antidiabetic activity of Syzygium cuminii $(L)$ skeel is due to its insulin release-stimulatory effects [21]. The study proved the impact of environmental factors on biosynthesis and productivity of secondary metabolites (bioactives) in medicinal plant. Gupta et al [22] reported that the therapeutic potential of Eugenia jambolana (Syzygium cuminii $(L)$ skeel) was related to the effect of Brazilian and Indian Eugenia jambolana's leaves on diabetes [23]. The considerable effect of morbidity and mortality worldwide [24]due to diabetic, and its treatment with medicinal plants especially Syzygium cumini (L) skeel with seeds, bark, and leaf (root not reported); this justifies the choice of root in the present study.

The novelty of finding was achieved with the evidence represented in Table-5 ctivity with isolated molecule has potent antidiabetic activity compared with standard anti-diabetic Glibincalamide. Glibenclamide was chosen as a standard drug in our study due to its properties to stimulate insulin secretion from pancreatic-cells [25], and our finding confirms the stimulatory effect of Target molecule (TM) on b-cells. 
The total synthesis of activity-guided bioactive was a unique approach to develop the molecule by applying retrosynthetic strategy, and the analytical parameters obtained from synthesized molecule showed similar chemical properties when compared with isolated pure bioactive. Hence, our results proved that the synthesis of bioactive could be possible way to regenerate the B-cells, and further study is in progress to assess the immune-stimulatory effect of TM.

\section{Conclusions}

Syzygium cumini (L.) Skeels root extract significantly lowered blood glucose level in all experimental models, which has not been reported earlier. We found marked degranulation of $\beta$-cells in various treatment of aqueous and synthesized molecules by stimulating insulin release through $\beta$-cells as compared to the control by secretogogue and glycogenesis effect. Hence, we selected the screx-1 for total synthesis which we achieved by applying simple DielsAlder reaction to assemble the complex molecule as significant natural bioactive. This novel finding would create scope to formulate natural anti-diabetic medicine with sustainable synthetic process.

\section{Funding}

This research received no external funding.

\section{Acknowledgments}

Authors are grateful to Mumbai University and Anjuman-I-Islam's Kalsekar Technical Campus for providing financial and technical and supports to carry out the pilot study.

\section{Conflicts of Interest}

The authors declare no conflict of interest.

\section{References}

1. Shafi, P.M.; Rosamma, M.K.; Jamil, K.; Reddy, P.S. Antibacterial activity of Syzygium cumini and Syzygium travancoricum leaf essential oils. Fitoterapia 2002, 73, 414-416, doi:10.1016/S0367326X(02)00131-4.

2. Oliveira, A.C.P.; Endringer, D.C.; Amorim, L.A.S.; Brandão, M.D.G.L.; Coelho, M.M. Effect of the extracts and fractions of Baccharis trimera and Syzygium cumini on glycaemia of diabetic and non-diabetic mice. $J$. Ethnopharmacol. 2005, 102, 465-469, doi:10.1016/j.jep.2005.06.025.

3. Gupta, S.S. Prospects and perspectives of natural plants products in medicine. Indian J. Pharmacol. 1994, 26, 1-12.

4. Zhi, P.R.; Liang, L.Z.; Yi, M.L. Evaluation of the antioxidant activity of syzygium cumini leaves. Molecules 2008, 13, 2545-2556, doi:10.3390/molecules13102545.

5. Ayyanar, M.; Subash-Babu, P.; Ignacimuthu, S. Syzygium cumini (L.) Skeels., a novel therapeutic agent for diabetes: Folk medicinal and pharmacological evidences. Complement. Ther. Med. 2013, 21, 232-243, doi:10.1016/j.ctim.2013.03.004.

6. Ramya, S.; Neethirajan, K.; Jayakumararaj, R. Profile of bioactive compounds in Syzygium cumini-a review. Artic. J. Pharm. Res. 2013, 5, 4548-4553.

7. Nikhat, F.; Satyanarayana, D.; Shastri, C.; Rajni, S.; Sheikh, A. The Phytochemicals explored from the roots of Syzygium cuminni (L) skeel assessed for Anti-hyperglycemic activity. Asian J. Res. Chem. 2013, 6, 920925.

8. Dudley, G.B.; Danishefsky, S.J. A four-step synthesis of the hydroazulene core of guanacastepene. Org. 
Lett. 2001, 3, 2399-2402, doi:10.1021/o1016222z.

9. Pepato, M.T.; Folgado, V.B.B.; Kettelhut, I.C.; Brunetti, I.L. Lack of antidiabetic effect of a Eugenia jambolana leaf decoction on rat streptozotocin diabetes. Brazilian J. Med. Biol. Res. 2001, 34, 389-395, doi:10.1590/S0100-879X2001000300014.

10. Brito, F.A.; Lima, L.A.; Ramos, M.F.S.; Nakamura, M.J.; Cavalher-Machado, S.C.; Siani, A.C.; Henriques, M.G.M.O.; Sampaio, A.L.F. Pharmacological study of anti-allergic activity of Syzygium cumini (L.) Skeels. Brazilian J. Med. Biol. Res. 2007, 40, 105-115, doi:10.1590/S0100-879X2007000100014.

11. Helmstädter, A. Syzygium cumini (L.) Skeels (Myrtaceae) against diabetes - 125 Years of research. Pharmazie 2008, 63, 91-101, doi:10.1691/ph.2008.7335.

12. Bhatia, I.S.; Bajaj, K.L. Chemical constituents of the seeds and bark of Syzygium cumini. Planta Med. 1975, 28, 346-352, doi:10.1055/s-0028-1097868.

13. Caporale, L.; Nutt, R.; Levy, J.; Smith, J.; Arison, B.; Bennett, C.; Albers-schonberg, G.; Pitzenberger, S.; Rosenblatt, M.; Hirschmann, R. Characterization of Synthetic Parathyroid Hormone Analogues and of Synthetic Byproducts. J. Org. Chem. 1989, 54, 343-346, doi:10.1021/jo00263a016.

14. Mahmoud, I.I.; Marzouk, M.S.A.; Moharram, F.A.; El-Gindi, M.R.; Hassan, A.M.K. Acylated flavonol glycosides from Eugenia jambolana leaves. Phytochemistry 2001, 58, 1239-1244, doi:10.1016/S00319422(01)00365-X.

15. Shibasaki, M.; Boden, C.D.J.; Kojima, A. T E T R A H E D R O N REPORT N U M B E R 421 The Asymmetric Heck Reaction. 1997, 53, 7371-7395.

16. Twaij, H.A.A.; Al-Badr, A.A. Hypoglycemic activity of Artemisia herba alba. J. Ethnopharmacol. 1988, 24 , 123-126, doi:10.1016/0378-8741(88)90143-2.

17. Queries, J.R. Chat Invitation. 2020, 1-3.

18. Kumar, A.; Ilavarasan, R.; Jayachandran, T.; Deecaraman, M.; Aravindan, P.; Padmanabhan, N.; Krishan, M.R. V Anti-diabetic activity of Syzygium cumini and its isolated compound against streptozotocin-induced diabetic rats. J. Med. Plants Res. 2013, 2, 246-249.

19. Trojan-Rodrigues, M.; Alves, T.L.S.; Soares, G.L.G.; Ritter, M.R. Plants used as antidiabetics in popular medicine in Rio Grande do Sul, southern Brazil. J. Ethnopharmacol. 2012, 139, 155-163, doi:10.1016/j.jep.2011.10.034.

20. Smaligo, A.J.; Vardhineedi, S.; Kwon, O. Carvone-Derived P-Stereogenic Phosphines: Design, Synthesis, and Use in Allene-Imine [3 + 2] Annulation. ACS Catal. 2018, 8, 5188-5192, doi:10.1021/acscatal.8b01081.

21. Ayyanar, M.; Subash-Babu, P. Syzygium cumini (L.) Skeels: A review of its phytochemical constituents and traditional uses. Asian Pac. J. Trop. Biomed. 2012, 2, 240-246, doi:10.1016/S2221-1691(12)60050-1.

22. Silva, S. do N.; Abreu, I.C.; Silva, G.F.C.; Ribeiro, R.M.; Lopes, A. de S.; Cartágenes, M. do S. de S.; Freire, S.M. de F.; Borges, A.C.R.; Borges, M.O. da R. The toxicity evaluation of Syzygium cumini leaves in rodents. Brazilian J. Pharmacogn. 2011, 22, 102-108, doi:10.1590/S0102-695X2011005000181.

23. Bag, A.; Bhattacharyya, S.K.; Pal, N.K.; Chattopadhyay, R.R. In vitro antibacterial potential of Eugenia jambolana seed extracts against multidrug-resistant human bacterial pathogens. Microbiol. Res. 2012, 167, 352-357, doi:10.1016/j.micres.2012.02.005.

24. Dos Santos, K.K.A.; Matias, E.F.F.; Tintino, S.R.; Souza, C.E.S.; Braga, M.F.B.M.; Guedes, G.M.M.; Rolón, M.; Vega, C.; De Arias, A.R.; Costa, J.G.M.; et al. Cytotoxic, trypanocidal, and antifungal activities of Eugenia jambolana L. J. Med. Food 2012, 15, 66-70, doi:10.1089/jmf.2010.0298.

25. Baliga, M.S.; Fernandes, S.; Thilakchand, K.R.; D’Souza, P.; Rao, S. Scientific validation of the antidiabetic effects of syzygium jambolanum dc (black plum), a traditional medicinal plant of india. J. Altern. Complement. Med. 2013, 19, 191-197, doi:10.1089/acm.2011.0752. 